\title{
CONTROL OF UNWANTED HARDWOODS IN NATIVE FOREST
}

\author{
A. E. BEVERIDGE
}

Forest Research Institute, N.Z. Forest Service, Rotorua

\section{Summary}

Chemical methods of controlling woody weed species are described. Most trees of less than $12 \mathrm{in}$. diameter can be killed by basal spraying with 2,4,5-T or by frill poisoning with ammonium sulphamate. Large stems may be poisoned with cacodylic acid applied to bored holes, and young growth can be controlled by low-volume foliage spraying with a mist blower. Aerial spraying of taller growth gives rapid desiccation of leaves and twigs, but this may be insufficient to permit burning. Costs are given for different methods of site preparation in old cut-over forest in a high-rainfall area. Fire and machines are likely to be the main tools for removing a heavy overwood, but chemicals may have a subsidiary role.

\section{INTRODUCTION}

Most experimental work by the Forest Research Institute on control of native hardwoods has been carried out in central North Island forests, mainly on soils derived from volcanic ash, at altitudes of 1,000 to $2,000 \mathrm{ft}$ above sea level, where annual rainfall ranges from 50 to $90 \mathrm{in}$.

Earlier work by the Forest Service on chemical methods of controlling native vegetation is recorded in the proceedings of a symposium held at the Forest Research Institute, Rotorua (Beveridge and Hedderwick, 1962).

The first Forest Research Institute trials were undertaken to find a cheap method of releasing native timber species from competition by shrub hardwoods*, which usually coppice vigorously when cut: the methods tried were stem poisoning and ground application of foliage sprays. Chemical methods have been preferred to simple ring girdling, as the latter has proved laborious and unreliable. Girdled species may recover by coppicing, and it is often difficult to completely girdle irregular stems. Ring girdling, however, is still used in some Forest Service field operations, particularly for killing large cull beech (Nothofagus spp.) and kanuka (Leptospermum ericoides). More recent trials have been concerned with killing large unmerchantable trees such as kamahi (Weinmannia: racemosa), and unmerchantable beech and tawa (Beilschmiedia tawa).

This paper consists of two parts, Part 1 on chemical methods of controlling woody weeds, and Part 2 on methods of preparing sites in derelict cut-over forest for the planting of exotic conifers.

\section{PART 1: CHEMICAL METHODS OF CONTROLLING WOODY WEEDS}

Control by Stem Treatments

Chemicals used experimentally include sodium arsenite, ammonium sulphamate, 2,4,5-T, 2,4-D, picloram, and cacodylic acid, but the last two have not been thoroughly tried.

* Large-leaved mesophytic species reaching 15 to $25 \mathrm{ft}$ in height. 
For regular stems over 4 in. in diameter, application of chemicals to complete frills has generally been the most effective treatment. A frill consists of a single horizontal line of overlappino cuts made with a hatchet. The frill cuts should penetrate the outer $1 / 2$ in. of sapwood. Application of chemicals to notches spaced round the stem may kill small specimens of particularly susceptible species, but, as there is little lateral movement of chemicals in the stems of most native hardwoods, the notching method is unreliable.

Basal spraying with phenoxyacetics in a diesel oil carrier is very effective for small stems, and may be the only practical stem treatment for multi-stemmed clumps. This method may also be used to treat large, irregular stems of susceptible species that are difficult to frill adequately, but the high volumes required make it wasteful where most of the stems exceed 4 to 6 in. in diameter.

Application of chemicals to holes bored in the stem by a powered drill is a promising method for killing large trees of species such as beech or kamahi.

The most rapid and consistent results have generally been obtained by treatment in the period November to February.

\section{Sodium Arsenite}

For all shrub hardwoods and most larger hardwoods tested, sodium arsenite is the cheapest and most rapidly effective poison for application to frills. Only tawa and rewarewa (Knightia excelsa) have been found resistant. When an aqueous solution containing $2 \mathrm{lb} \mathrm{As}_{2} \mathrm{O}_{3}$ per gallon is used, little more is required than dampening of the cambial area exposed by frilling. Since 1962, however, the New Zealand Forest Service has banned the use of inorganic arsenicals for poisoning in State forests. Chemicals less toxic to humans must therefore be substituted if possible.

Nevertheless, some experimental work has since been done to find safer methods of using arsenicals. Plastic squeeze bottles with a nozzle aperture $1 \mathrm{~mm}$ across were used in field trials to apply a minimum amount of solution to frills. The volume used was $2.5 \mathrm{ml}$ per inch of stem diameter. This is a comparatively safe method, but some contamination of gloves seems inevitable. In these trials operators used barrier cream on their hands and wore cotton gloves. Analysis of the gloves showed an arsenic content of $10 \mathrm{mg}$ per pair per hour of use.

Application to bored holes from a plastic container or a veterinary drenching gun appears to be an even safer method. A sodium arsenite concentrate containing $5.6 \mathrm{lb} \mathrm{As}_{2} \mathrm{O}_{3}$ per gallon was applied in December to large cull trees of silver beech (Nothofagus menziesii) and red beech ( $N$. fusca) in Kaimanawa North State Forest. Dosage was $10 \mathrm{ml}$ per hole, and holes were spaced at 16 in. intervals round the bole (approx. $2 \mathrm{ml}$ per inch of diameter). Judged by defoliation. mean crown death after one year was $93 \%$ for silver beech and $73 \%$ for red beech. The same treatment applied to large kamahi of epiphytic origin in Mamaku State Forest resulted in only $50 \%$ crown death after one year. A 6 in. interval between holes is recommended for a complete and rapid kill of beech and probably of other species.

\section{Cacodylic Acid}

Small pilot trials indicate that application of cacodylic acid to bored holes is a promising method for killing large trees of kamahi, tawa, and beech. A product containing $25 \%$ cacodylic acid was applied to kamahi and tawa in April at the rate of $10 \mathrm{ml}$ per hole, with holes spaced at 6 in. intervals around the stem (approx. $5 \mathrm{ml}$ per inch of diameter). Twelve months after treatment all the 
kamahi were completely defoliated and tawa were 70 to $90 \%$ defoliated. (There is some evidence that tawa is more susceptible to autumn treatment with arsenicals than to summer treatment.) Dosages of $1 \mathrm{ml}$ per inch of diameter applied in December were relatively ineffective.

Southland Conservancy has found that cacodylic acid is effective on cull silver beech when applied at the rate of $10 \mathrm{ml}$ per hole to holes bored $6 \mathrm{in}$. apart, but consider that this method is at present too expensive to use on a large scale.

\section{Ammonium Sulphamate}

For shrub hardwoods, and for small stems of large tree species, ammonium sulphamate is the cheapest and most satisfactory substitute for sodium arsenite so far tested, although it kills trees less rapidly. It is not effective on tawa or large stems of kamahi and rewarewa, and high dosages of a saturated solution (15 lb crystals to 1 gal water) are required for large beech. Southland Conservancy reports that a liberal application to complete frills has given a good kill of silver beech, and that a dosage of $10 \mathrm{ml}$ per hole applied in April to holes bored 6 in. apart killed $81 \%$ of trees in seven months. A suitable concentration for frill application to shrub hardwoods is $4 \mathrm{lb}$ of crystals to $1 \mathrm{gal}$ of water. Dosage should be more liberal than in the case of arsenicals; a volume of $10 \mathrm{ml}$ per inch of diameter has been found effective. Lower dosages produce uncertain results. The method of applying crystals to stem notches is not suitable for most native hardwoods.

\section{2,4,5-T and 2,4-D}

2,4,5-T has given more reliable results than 2,4-D, but most shrub hardwoods are susceptible to both chemicals. Most of the experimental work has been done with oil-miscible, low-volatile esters, the butoxyethanol ester in particular.

$2,4,5-\mathrm{T}$ in diesel oil has been effective when applied to frills or as a basal spray for shrub hardwoods and rewarewa of any size, but poor results have been obtained with kamahi and with some other tree species over 6 in. d.b.h. Tawa less than 6 in. d.b.h. is killed within a few months by basal spraying, but larger specimens should be treated by spraying into and adjacent to a basal frill; the frill cuts ensure that the spray reaches the cambial region. Tawa treated in this way may take two years or more to die.

In Mamaku Forest field trials, a basal spray containing 2,4,5-T in diesel oil at $14.4 \mathrm{lb}$ acid equivalent per 100 gal (a.h.g.) has given good results with highly susceptible shrub hardwoods when applied in summer to dry or slightly damp bark. For general use a concentration of $20 \mathrm{lb}$ a.h.g. is recommended for spraying at a volume of $40 \mathrm{ml}$ per inch of breast-height diameter. This volume enables a liberal application to be made to the basal 6 in. of bark and prevents growth of coppice shoots. The same treatment may be given to freshly cut stumps to prevent coppice growth but the cut surface of the stump should also be sprayed (Beveridge, 1965a). In trials with measured dosages, many thin-barked species have been killed with dosages of $10 \mathrm{lb}$ a.h.g. applied at the rate of $20 \mathrm{ml}$ per in. diameter as a basal spray and $10 \mathrm{ml}$ per in. diameter applied to frills. Aqueous solutions of amine salts of 2,4,5-T and 2,4-D applied to frills at similar dosage rates have given rather poorer results compared with the ester in diesel oil; low dosages of concentrated amines have been used successfully overseas but have not been tested by the New Zealand Forest Service. 


\section{Picloram}

Applications of concentrated and dilute solutions containing the amine salts of picloram and 2,4,5-T* and of a solution containing $0.75 \mathrm{lb}$ per gallon of the potassium salt of picloram to bored holes in large beech, kamahi, and tawa gave poor results after one year there was little defoliation between six and 12 months after treatment. Volumes used were low (1-2 ml per inch of diameter), but higher dosages would not be economic.

\section{Control by Ground Application of Foliage Sprays}

Good spray coverage with 2,4,5-T butoxyethanol ester applied from a knapsack-type mist blower at the rate of $1 \mathrm{lb}$ acid equivalent in $10 \mathrm{lb}$ carrier per acre has given good control of most common hardwood species on the Mamaku Plateau (Beveridge, $1965 \mathrm{~b}$ ). Both midsummer and autumn treatments have been effective and, with the exception of mahoe (Melicytus ramiflorus) there has been little recovery of vegetation under $5 \mathrm{ft}$ high. A diesel oil carrier has given the best kill, but a complete kill of hardwood vegetation often results in a dense cover of resistant ferns and monocotyledons. Spraying with an emulsifiable ester of 2,4,5-T in a water carrier has given good release of conifers from competition by shrub hardwoods.

In the small-scale work so far undertaken, 2,4-D esters appear to have no advantage over 2,4,5-T. One of the most common woody species, wineberry (Aristotelia serrata), appears to be comparatively resistant to 2,4-D but extremely susceptible to 2,4,5-T when in the full-leaf stage; cotyledonary seedlings, however, resisted autumn spraying with $1 \mathrm{lb} 2,4 ; 5-\mathrm{T}$ per acre in an oil-and-water carrier.

Aerial spraying of dense vegetation 15 to $30 \mathrm{ft}$ high is referred to in Part 2.

\section{PART 2: SITE-PREPARATION TRIALS IN SOUTH MAMAKU FOREST}

The object of these trials in old cut-over forest is to find the most economic and effective method of removing a dense overwood and preparing a site suitable for planting exotic conifers. The methods involve the use, singly or in combination, of felling, fire, tractors, and herbicides. Evaluation will be done on the basis of cost, area of plantable ground recovered, and early performance of planted species (mainly Pinus radiata and Pseudotsuga menziesii).

Easy terrain enabled treatments to be done in roughly comparable blocks, most of which were 10 acres in extent. Native conifers (podocarps) had been logged in the trial area 25 years ago, and before treatment there was a dense growth of shrub hardwoods 15 to $25 \mathrm{ft}$ high, with tree ferns and taller residual stems including kamahi and tawa. The composition of one representative acre of such forest is given in Table 1 , and costs of treatment are given in Table 2.

* Concentrate contains $2 \mathrm{lb}$ of 2,4,5-T plus $0.75 \mathrm{lb}$ picloram per gallon. 


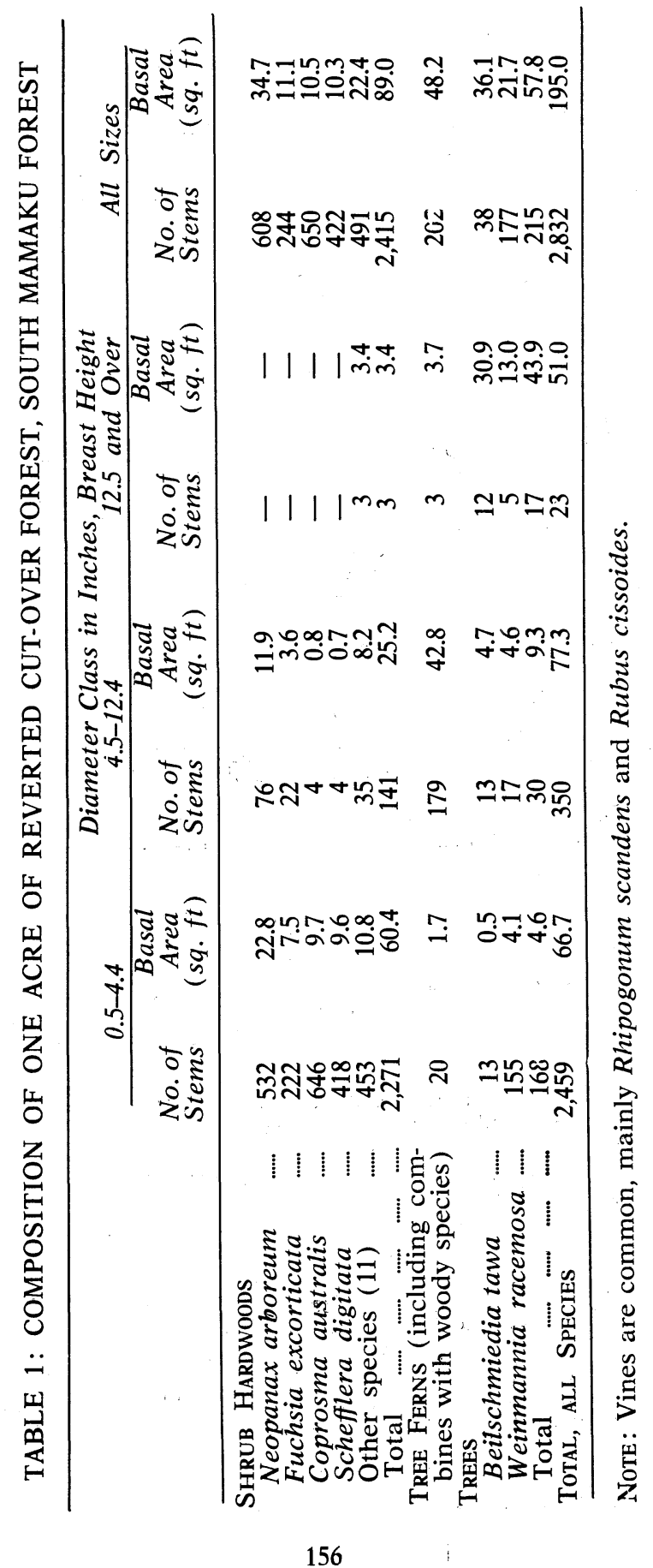




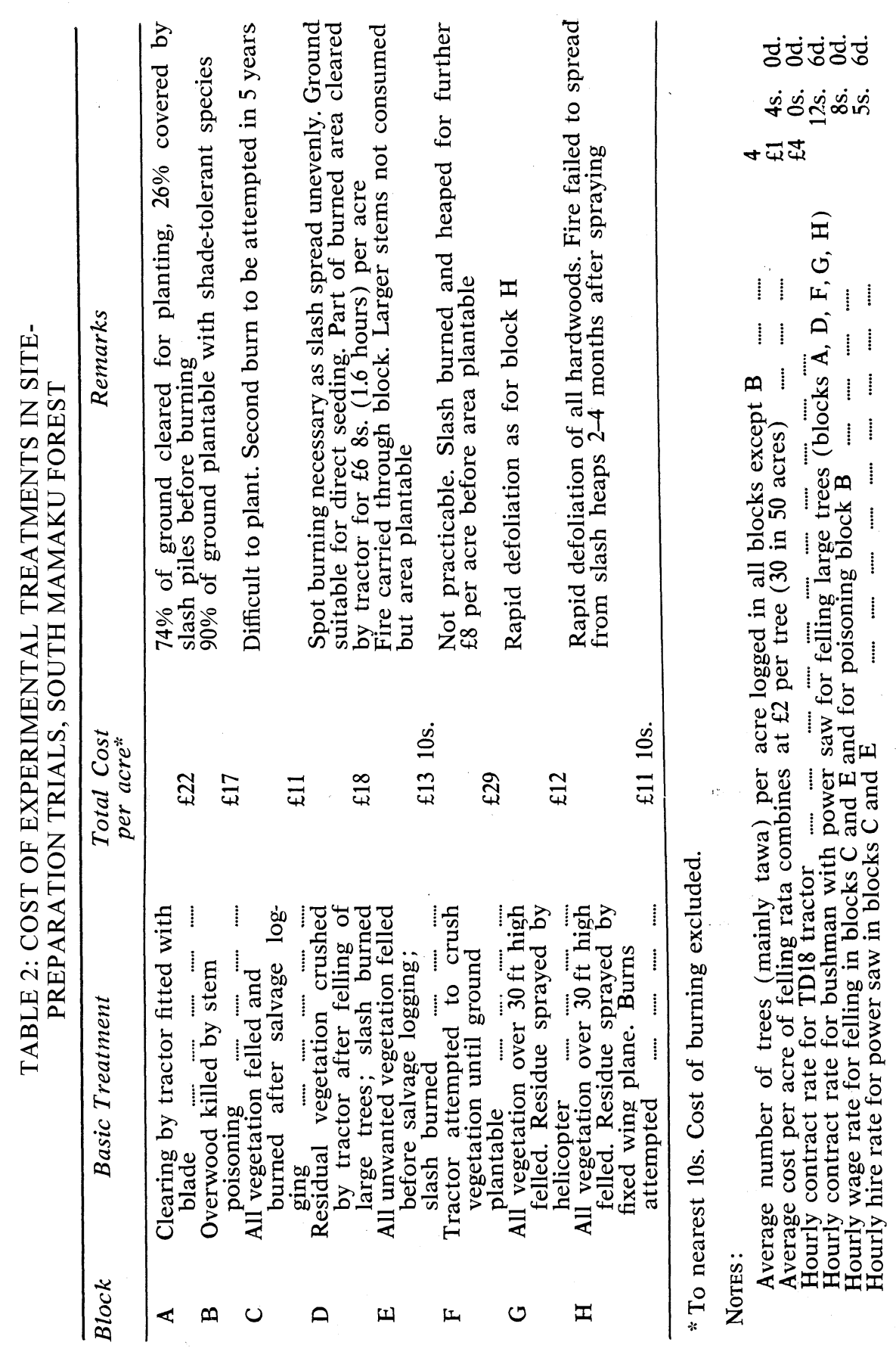




\section{Discussion}

\section{Tractor Clearing}

Tractor clearing (block A) is suitable for easy terrain where a light-demanding, frost-resistant species is to be planted. Weed growth is reduced by removal of topsoil and frosting of shrub-hardwood seedlings. Slash heaps were burned a year after piling; total plantable ground was then estimated at $90 \%$ of the block. Costs per acre comprised:

$\begin{array}{llllll}\text { Tractor time }(4.5 \text { hours }) & \ldots \ldots . & \ldots . . . & \ldots . . . & \ldots . . . & \ldots . . . \\ \text { Felling large trees, including rata } & & \ldots . . . & \ldots . . . & \ldots . . .\end{array}$

Tractor clearing of spot-burned slash in block D showed that this method gives a maximum area of plantable ground at a cost of 1.6 tractor-hours per acre. Thus, where the labour is available for felling, tractor clearing of felled and burned slash would cost a total of approximately $£ 20$ per acre, and ground would be less compacted than if living vegetation were piled.

\section{Felling and Burning}

Method E, where all stems are felled and none crushed by logging (cf. block $\mathrm{C}$ ), has given an adequate burn, but the comparatively low cost of treatment ( $£ 1310 \mathrm{~s}$. 0d. per acre) may be offset by difficult planting conditions and growth of wineberry sheltered by unconsumed slash. Felling time per acre involved 15.6 man-hours for slasher cutting and 9.9 man-hours for chain-saw cutting. Felling and burning may be the only practicable method on steeper terrain and direct seeding is feasible where much of the slash is not consumed.

\section{Use of Herbicides}

Killing of the overwood by stem poisoning (block B) leaves topsoil intact, lessens the severity of frost, and enables good growth to be made by shade-tolerant species that can compete in their second year with a vigorous growth of shrub hardwoods and ferns. Cost per acre comprised:

Basal spraying (mainly smaller stems):

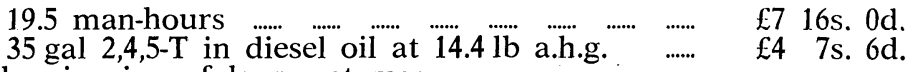

Frill poisoning of larger stems:

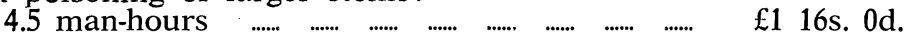

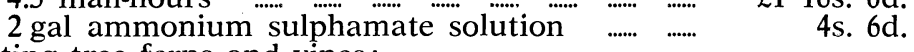

Cutting tree ferns and vines:

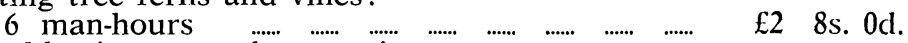

Mist blowing ground vegetation:

1 man-hour, applying $1 \frac{1}{2}$ gal $2,4,5-\mathrm{T}$ at $10 \mathrm{lb}$ a.h.g. in an oil-water carrier .................

Total

$£ 17$ 2s. 0d.

Aerial spraying in December (blocks $G$ and $H$ ) resulted in an almost complete leaf fall or leaf kill of hardwoods in one month, but in a climate such as that of the Mamaku plateau only exceptional conditions would enable a crown or ground fire to travel through standing, partly desiccated vegetation. Fine fuel conditions were good but lack of wind and flat terrain contributed to the failure to obtain a satisfactory burn. Samples taken from the stems of leafless specimens of the main species three months after spraying had moisture contents ranging from $100 \%$ to $180 \%$ of oven-dry 
weight. Comparison with similar samples from an unsprayed block showed that leafless sprayed stems had lost little moisture at the times when burns were attempted. Twigs, however, had dried out to varying degrees, the lowest moisture content being $28 \%$ for wineberry, a species that is likely to die.

Costs per acre in block $H$ comprised:

Felling unmerchantable trees over $30 \mathrm{ft}$ high

(except rata):

6.3 man-hours (average cost based on 30 acres) Felling rata (average cost based on 50 acres) Flying to distribute 20 gal spray per acre 20 gal spray containing $7.2 \mathrm{lb} 2,4,5-\mathrm{T}$ in diesel oil ......

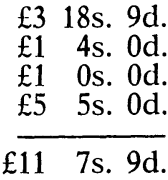

An acre of this leafless and partly burned vegetation could probably be cleared by tractor in two hours, so that the total cost of preparation (about $£ 20$ ) would be comparable with that of other methods tested. Such desiccation would give greater visibility for tractor clearing and would cause the slash from large felled trees to become inflammable more rapidly. Burned slash breaks up when pushed with a tractor blade, and is easier to move than green material.

\section{CONCLUSIONS}

Basal spraying with phenoxyacetics is a suitable method of killing stems less than 5 in. d.b.h. Arsenicals are the most effective poisons for larger stems but they can be dangerous to use. For trees of 5 to 12 in. d.b.h. a solution of ammonium sulphamate applied to complete stem frills is safe to use and reasonably effective; results are less certain for trees over $12 \mathrm{in}$. d.b.h. and a more effective but more expensive treatment is the application of cacodylic acid to holes bored 6 in. apart round the stems.

For piecemeal ground treatment, foliage spraying with a mist blower is a useful method for controlling vegetation less than $5 \mathrm{ft}$ high.

In dense, old, cut-over forest of the Mamaku plateau, most methods of site preparation will cost at least $£ 20$ per acre. On easy terrain, good planting conditions can be obtained by using a tractor to pile up felled and burned vegetation. On steeper terrain where the overwood has been felled and burned, direct seeding is a possibility. Aerial spraying with herbicides can quickly defoliate the vegetation; this could be an aid to tractor clearing and the drying out of large, felled material in preparation for burning. Trials in Mamaku Forest indicate that it is unlikely that aerial spraying alone will cause enough desiccation to enable a crown fire to pass through a whole block.

\section{ACKNOWLEDGEMENTS}

The co-operation of Rotorua forest conservancy staff is gratefully acknowledged. D. S. Preest of the Forest Research Institute supervised the aerial spraying and Forest Ranger B. Klomp assisted in the field.

\section{REFERENCES}

Beveridge, A. E., 1965a: N.Z. For. Serv. Res. Note 41

1965b: N.Z. For. Res. Inst. Leafl. 8

Beveridge, A. E.; Hedderwick, G. W. (editors) 1962: Chemical methods of vegetation control in New Zealand forestry; Proceedings of a symposium held at the Forest Research Institute, July, 1962. The Institute, Rotorua. 